\title{
First report of Podosphaera xanthii causing powdery mildew on Xanthium strumarium in India
}

\author{
Sachin Vasantrao Thite ${ }^{1} \cdot$ Basavaraj A. Kore ${ }^{1}$ Moisés Camacho-Tapia ${ }^{2} \cdot$ Juan Manuel Tovar-Pedraza $^{2}$
}

Published online: 5 March 2018

(C) Società Italiana di Patologia Vegetale (S.I.Pa.V.) 2018

Xanthium strumarium (Asteraceae) is a notorious weed and has been extensively naturalized in India as a common weed (Oudhia and Dixit 1994). During September and October 2016, a powdery mildew infection was observed on leaves of $X$. strumarium in Satara District of Maharashtra, India. Symptoms appeared as sparse white colonies, which subsequently developed abundant growth on adaxial leaf surfaces. The morphological examinations of the fungus revealed mycelium amphigenous, in irregular patches or effuse, thin to dense, evanescent to persistent. The hyphal appressoria were slightly nipple-shaped and solitary. Conidiophores were erect, arising from the upper surface of hyphal mother cells, mostly towards one end of the cell. Foot cells were cylindrical, 40$80 \times 10-13 \mu \mathrm{m}$, sometimes slightly constricted at the basal septum or slightly swollen at the base, followed by $1-3$ shorter

Juan Manuel Tovar-Pedraza

jmtovar@colpos.mx

1 Department of Botany, Yashvantrao Chavan Institute of Science, Satara, Maharashtra 415001, India

2 Departamento de Parasitología Agrícola, Universidad Autónoma Chapingo, Km 38.5 Carretera México-Texcoco, Chapingo, 56230 Texcoco, Estado de México, Mexico cells. Catenescent conidia, ellipsoid-ovoid to doliiform, 29$42 \times 16-21 \mu \mathrm{m}$, with germ tubes \pm lateral, simple to forked. Chasmothecia were not observed. Based on the morphological characteristics, the pathogen was identified as Podosphaera xanthii (Braun and Cook 2012). A reference specimen (HAL-2912F) was deposited in the Herbarium of the Martin Luther University, Halle, Germany. Total fungal DNA of one representative isolate was used for amplification of the internal transcribed spacer (ITS) ribosomal DNA using universal primers ITS5 and ITS4 (White et al. 1990), sequenced and deposited in GenBank (accession No. KX369236). BLASTn analysis showed $100 \%$ identity with that of $P$. xanthii from Verbena bonariensis from Japan (AB462804). To our knowledge, this is the first report of $P$. xanthii on $X$. strumarium in India.

\section{References}

Braun U, Cook RTA (2012) Taxonomic manual of the Erysiphales (powdery mildews). CBS-KNAW Fungal Biodiversity Centre, Utrecht

Oudhia P, Dixit A (1994) Weeds in Ambimkapur region (Madhya Pradesh) and their traditional use. Weed News 1:19-21

White TJ, Bruns T, Lee S, Taylor J (1990) Amplification and direct sequencing of fungal ribosomal RNA genes for phylogenetics. In: Innis MA, Gelfand DH, Sninsky JJ, White TJ (eds) PCR protocols: a guide to methods and applications. Academic, San Diego, pp 315-322 